\title{
Aspergillus versicolor
}

National Cancer Institute

\section{Source}

National Cancer Institute. Aspergillus versicolor. NCI Thesaurus. Code C127688.

A species of slow-growing filamentous fungi in the phylum Ascomycota with long, septate hyphae and conidiophores that terminate in small vesicles. This species is commonly isolated from soil and plant debris and is among the most common of indoor molds. 